\title{
A Nova Literatura Infantil Sob o Ponto de Vista da Autoria
}

\author{
Ricardo Ramos Filho ${ }^{1}$
}

\begin{abstract}
Resumo
Este trabalho tem como objetivo discutir, sob o ponto de vista da autoria, a Literatura Infantil escrita nos dias de hoje, observando as relações dinâmicas entre autor, obra e leitor que, segundo Antonio Candido, formariam um tipo de comunicação inter-humana chamada literatura. Até que ponto esse sistema continua válido quando pensamos no ampliado número de "autores" que participam da criação de uma obra escrita para crianças atualmente? Mais do que isso, o sistema abrigaria a própria Literatura Infantil?
\end{abstract}

\begin{abstract}
This paper aims to discuss, from the point of view of the authors, children's literature written today, watching her from the point of view of dynamic relationships between author, work and reader that, according to Antonio Candido, would form a inter-human communication called literature. To what extent this system is still valid when we expanded the number of "authors" who participate in the creation of a work written for children today? More than that, discuss if the system itself includes Children's Literature as part of it.
\end{abstract}

PALAVRAS-CHAVE: Literatura Infantil; Autor; Obra; Leitor

KEYWORDS: Children's Literature; Author; Work; Reader

\footnotetext{
${ }^{1}$ Roteirista e escritor premiado, autor de livros de Literatura Infantil e Juvenil; mestrando na área de Estudos Comparados de Literaturas de Língua Portuguesa - Universidade de São Paulo.
} 


\section{Nota Introdutória}

Ao iniciarmos nossas considerações, precisamos retomar claramente 0 pensamento de Antonio Candido, pois é partindo dele que iremos elaborar este artigo. Para ele, alguns elementos se distinguem na formação do sistema literário:

A existência de um conjunto de produtores literários, mais ou menos conscientes de seu papel; um conjunto de receptores, formando os diferentes tipos de público, sem os quais a obra não vive; um mecanismo transmissor, (de modo geral, uma linguagem, traduzida em estilos), que liga uns aos outros. $\mathrm{O}$ conjunto dos três elementos dá lugar a um tipo de comunicação inter-humana, a literatura, que aparece sob este ângulo como sistema simbólico, por meio do qual as veleidades mais profundas do indivíduo se transformam em elementos de contato entre os homens, e de interpretação das diferentes esferas da realidade (CANDIDO, 2009, p. 25).

Partindo do exposto, somos levados a um pensamento mais amplo: até que ponto esse sistema continua válido quando definimos Literatura Infantil? Mais do que isso, faz sentido considerarmos essa "tríade" quando o universo em questão, o dos dias atuais, amplia tanto cada um dos elementos do conjunto?

A nossa intenção, aqui, é centrarmos atenção na questão da autoria, no conjunto dos produtores literários, destacando a evidência de que a obra já não é mais a mesma.

\section{Os Mecanismos Transmissores}

Facilidades gráficas e computacionais cada vez mais disponíveis tornaram a imagem um elemento sempre mais frequente nas obras literárias. Segundo Maria Zilda da Cunha (2009), na perspectiva dos estudos de literatura, procurar relações entre a palavra e a imagem já tem se mostrado o caminho natural. A bem da verdade, desde sempre, é no seio da palavra poética que a imagem, em todas as suas manifestações multiformes, fez e continua fazendo seu ninho. Além disso, é primordial para a compreensão da literatura a forma como linguagens verbais e não-verbais se entrelaçam, se entretecem, pois o fascínio e o enigma que sempre caracterizaram a criação viva e inovadora da literatura é o seu trânsito entre o verbal e o não-verbal (CUNHA, 2009, p. 141).

Há, porém, necessidade de se ampliar, cada vez mais, a abrangência do não-verbal que, com o tempo, atingiu sentidos que vão além do visual, tais como: o táctil e o sonoro, por exemplo, fazendo com que se torne difícil até mesmo, muitas vezes, denominar a obra de livro. Apesar de não haver dúvida, conforme afirma João Alexandre Barbosa (1999), que a importância cultural do 
livro seja elemento intrinsecamente vinculado à presença do livro enquanto objeto que, como tal, traduz, para os sentidos, aquela importância. Mesmo porque, enquanto objeto, o livro emite sinais culturais que são decodificados pelos sentidos e que o instituem como obra de arte: tipologias, dimensões, equilíbrios, simetrias, cores, ilustrações etc. Por isso, é possível falar numa paixão pelo livro (BARBOSA, 1999, p. 27-28). Essa paixão, porém, em termos de literatura, irá se deslocar para um mecanismo transmissor diferente, pois, ao fazerem uso das novas tecnologias midiáticas, os artistas expandiram o campo das artes para as interfaces com o desenho industrial, a publicidade, 0 cinema, a televisão, a moda, as subculturas jovens, o vídeo, a computação gráfica etc. (SANTAELLA, 2008, p. 14). A obra, definitivamente, já não é mais a mesma, principalmente quando pensamos na que é destinada ao público infantil.

\section{Receptores Infantis}

As crianças exigem 0 novo, até porque observam com naturalidade o que muitas vezes nos parece estranho. Elas, devido às potencialidades do seu pensamento, são muito contemporâneas, isto é, atualizadas em suas concepções sobre o mundo: enxergam os sentidos nas frestas, fissuras e nichos, por onde conseguem escapar da lógica habitual. E estas frestas são cifras, nunca totalmente impenetráveis, nunca inteiramente transponíveis: o conhecimento humano é para elas sempre uma infinita abertura de possibilidades de pensamento e linguagens que, entretanto, não se confundem com a verdade (DEHEINZELIN, 1996, p. 22-23).

Para Walter Benjamin, as crianças têm um particular prazer em visitar oficinas onde se trabalha visivelmente com coisas. Elas se sentem atraídas irresistivelmente pelos detritos, onde quer que eles surjam - na construção de casas, na jardinagem, na carpintaria, na confecção de roupas. Nesses detritos, elas reconhecem 0 rosto que 0 mundo das coisas assume para elas, e só para elas. Com tais detritos, não imitam 0 mundo dos adultos, mas colocam os restos e resíduos em uma relação nova e original. Assim, as próprias crianças constroem seu mundo de coisas, um microcosmos no macrocosmos. O conto de fadas é uma dessas criações compostas de detritos - talvez a mais poderosa na vida espiritual da humanidade, surgida no processo de produção e decadência da saga. A criança lida com os elementos dos contos de fadas de modo tão soberano e imparcial como com retalhos e tijolos. Constrói seu mundo com esses contos, ou pelo menos os utiliza para ligar seus elementos (BENJAMIN, 2010, p. 237-238). Dentro deste contexto, e da maneira particular com que as crianças representam suas histórias, não nos parece que o fato das inovações tecnológicas terem ampliado sobremaneira as possibilidades de um conto ser apresentado, alterem consideravelmente o universo receptor em questão.

Para Maria José Palo e Maria Rosa D. Oliveira (2006), desde os primórdios, a Literatura Infantil surge como uma forma literária menor, atrelada à função utilitário-pedagógica que a faz ser mais 
pedagogia do que literatura. Contar histórias para crianças sempre expressou um ato de linguagem de representação simbólica do real direcionado para a aquisição de modelos linguísticos. O trabalho com tais signos remete o texto para alguma coisa fora dele, de modo a resgatar dados de um real verossímil para o leitor infantil. Este, tratado fisionomicamente sob o "modo de ser" do adulto, refletese para a produção infantil como um receptor engajado nas propostas da escola e da sociedade de consumo. Deverá, sobretudo, apreender, via texto literário infantil, a verdade social (PALO; OLIVEIRA, 2006, p. 9). Como não nos parece que essa proposta pedagógica tenha sido alterada, mesmo que com uma nova roupagem, a Literatura Infantil deverá continuar tendo o mesmo propósito. Resta apenas estudar mais profundamente, até que ponto esta nova "cara" é capaz de alterar a literariedade dos diversos textos que ela traz.

\section{O Conjunto dos Produtores Literários}

Ao começarmos nossa investigação sobre o conjunto dos produtores literários no mundo atual, é necessário que recuemos um pouco no tempo e observemos algumas questões levantadas por Roland Barthes (2009, p. 31-32):

Quem fala? Quem escreve? Falta-nos ainda uma sociologia da palavra. O que sabemos é que a palavra é um poder e que, entre a corporação e a classe social, um grupo de homens se define razoavelmente bem pelo seguinte: ele detém, em diversos graus, a linguagem da nação. Ora, durante muito tempo, provavelmente durante toda a era capitalista clássica, isto é, do século XVI ao $X I X$, na França, os proprietários incontestáveis da linguagem eram os escritores e somente eles; com exceção dos pregadores e dos juristas, fechados aliás em suas linguagens funcionais, ninguém mais falava; e essa espécie de monopólio da linguagem produzia curiosamente uma ordem rígida, menos dos produtores do que de produção: o que era estruturado não era a profissão literária (ela evoluiu muito durante três séculos, do poeta empregado ao escritor-homem de negócios), era a própria matéria desse discurso literário [...].

Interessa-nos, então, verificar como fica essa matéria de discurso literário nos dias de hoje. Mas partindo do princípio de que esse escritor-homem de negócios tornou-se membro de uma equipe de trabalho, deixando de assumir sozinho a responsabilidade pela autoria da obra. E que, ao inserir-se como mais um elemento da cadeia produtiva literária, ajuda a construir essa qualidade literária em um contexto em que não mais apenas o discurso verbal precisa ser considerado e privilegiado. Até porque esse escritor já não é mais o único que fala, já que outras vozes formam o verdadeiro "coral" literário que desenha os livros infantis contemporâneos. Obras que nascem de um esforço coletivo em que muitas vezes o editor (que representa interesses da própria editora, da escola e do governo), o escritor, o ilustrador, o projetista gráfico, o web designer, o músico, entre outros artistas, estão presentes e são também autores. E o autor deve, segundo Mikhail Bakhtin (2010), antes de tudo ser entendido a partir do acontecimento da obra como participante dela, como orientador autorizado do 
leitor. Precisamos compreender o autor no universo histórico de sua época, no seu lugar no grupo social, na sua posição de classe. No interior da obra, o autor é para o leitor o conjunto dos princípios criativos que devem ser realizados, a unidade dos elementos transgredientes da visão, que podem ser ativamente vinculados à personagem e ao seu mundo (BAKHTIN, 2010, p. 191-192). São esses os autores da obra moderna, sócios nessa transgressão da visão que origina o novo livro infantil.

Segundo Ana Maria Machado (2007), é importante pensarmos na intenção do autor quando nos damos conta de que, agora, a autoria é compartilhada. Frequentemente, um autor começa um livro sem saber como ele vai acabar e nem por onde ele vai se desenvolver. Para ela, é claro que muitas vezes se tem uma noção de para onde as coisas caminham, qual o vago objetivo a se alcançar. Mas tudo costuma ser muito mais vago do que o leitor imagina (MACHADO, 2007, p. 12). Parece-nos que seria exatamente essa brecha que permite que a obra seja mais facilmente desenvolvida por diversos artistas. Até porque, como afirma Umberto Eco, a obra de arte é uma mensagem fundamentalmente ambígua, uma pluralidade de significados que convivem num só significante. Essa condição constitui característica de toda obra de arte, e tal ambiguidade se torna uma das finalidades explícitas da obra, um valor a realizar de preferência a outros. E visando à ambiguidade como valor, os artistas contemporâneos voltam-se, consequentemente e amiúde, para os ideais da informalidade, desordem, casualidade, indeterminação dos resultados; daí porque se tentou também impor o problema de uma dialética entre "forma" e "abertura"; isto é, definir os limites dentro dos quais uma obra pode lograr o máximo de ambiguidade e depender da intervenção ativa do consumidor, sem contudo deixar de ser "obra" (ECO, 1971, p. 22-23).

Talvez estejam nesse anseio pelo ambíguo, aliado a certa indeterminação do percurso vista anteriormente, as maiores oportunidades de um trabalho conjunto. Até porque esse trabalho conjunto, na maioria das vezes, são diversos trabalhos isolados que se somam, posteriormente, com cada autor desempenhando sua parcela de responsabilidade pela obra isoladamente. Embora a autoria seja compartilhada, o trabalho em si do artista, quase sempre, continua sendo feito dentro de sua especialidade e com liberdade criativa individual. O resultado, geralmente, forma-se por meio da soma dessas perspectivas individuais que nem sempre são uníssonas. E talvez seja justamente nessa ausência de voz única que a ambiguidade se faça mais presente, ampliando as possibilidades da própria obra e sua literariedade.

Mas é dentro do contexto da intenção que os autores possam ter que pretendemos nos fixar mais um pouco. Até que ponto seria importante que o engajamento do autor, às vezes presente, também se fizesse de maneira conjunta? Para Benjamin Abdala Junior (2007), se as estruturas de profundidade que organizam o texto são frequentemente não-conscientes ao escritor, isso não significa que ele não possa procurá-las nos modelos da ideologia/cultura. A preocupação pelo trabalho consciente, entretanto, só será eficaz se não inibir ou o canalizar para a obediência acrítica de determinados 
figurinos. Essa conscientização dos processos artísticos tem sido uma preocupação central dos movimentos de vanguarda e ela poderá contribuir não só para as transformações da literatura, como também, para a própria realidade que cerca seu circuito de comunicação (ABDALA, 2007, p. 176). Isto posto, e mais uma vez, obedecida certa preocupação vanguardista editorial possivelmente presente, parece-nos que o engajamento individual de cada participante da obra, desde que seja feita uma leitura atenta por parte dos outros autores, que são também leitores, fatalmente será replicado no trabalho conjunto. Se não o for completamente, ao acentuar-se a ambiguidade do resultado final, ainda será possível termos uma obra de qualidade literária. Poderemos, então, falar em um engajamento coletivo que se faz presente na produção final, autoral, mesmo que os autores sejam muitos.

Para Antonio Candido (2009), a diferença entre um documento literário qualquer e a obra de arte literária reside, antes de tudo, no valor diverso da camada quase-sensível das palavras (sensível quando o texto é lido a viva voz). Este plano quase-sensível das palavras e de seus contextos maiores tem na literatura em sentido lato função puramente instrumental: a de projetar, como vimos, objectualidades puramente intencionais que, por sua vez, sem serem notadas com tais, se referem aos objetos visados. O que importa são os significados que se identificam com os objetos visados, não os significantes. Estes últimos - as palavras - se omitem por completo (da mesma forma que as objectualidades puramente intencionais); podem ser substituídos por quaisquer outros que constituam os mesmos significados. A relação entre a camada quase-sensível e a camada "espiritual" é, portanto, inteiramente convencional. A intenção do leitor passa diretamente ao "sentido" e aos objetos visados. $\mathrm{Na}$ obra de arte literária, esta relação deixa de ser convencional, apresenta necessidade e grande firmeza e consistência (CANDIDO et al, 2009, p. 38-39). Ao nos importarmos com os significados, e não com os significantes, das palavras, abrimos espaço para que outros significantes, tais como imagens, sons, e tudo o que a modernidade disponibiliza, façam parte dessa obra de arte literária. Todos os artistas envolvidos, os autores em questão, constroem essa literatura.

\section{Conclusão}

Enfim, mantém-se a literatura com um número ampliado de autores? Parece-nos que sim. O fundamental seria perceber que toda a multiplicidade que existe nos três elementos que, ao se relacionarem dinamicamente formam uma literatura, no final se transforma em unicidade. Assim como a obra, embora construída por diversos recursos, forma um todo que precisa ser olhado como objeto único, o leitor que a lê, embora domine uma infinidade de elementos, ainda continua sendo o mesmo leitor singular. Identicamente a autoria, ao fazer parte de um projeto autoral coletivo, permanece sendo autoria. Na prática, é como se houvesse um gerente do projeto que se responsabilizasse pelo todo. Na maior parte das vezes, no caso do livro impresso, esse autor "principal" ainda é considerado 
0 escritor do texto verbal.

E esse sistema continua válido quando falamos em Literatura Infantil? Parece-nos, novamente, que sim. Para Nelly Novaes Coelho, a Literatura Infantil, em essência, tem a mesma natureza da que se destina aos adultos. As diferenças que a singularizam são determinadas pela natureza de seu leitor/receptor: a criança (COELHO, 2009, p. 29). O fato do conjunto de receptores pertencer ao mundo infantil não altera em nada a definição construída por Antonio Candido, até porque ele em nenhum momento explicitou a exigência de um leitor adulto. 


\section{Referências}

ABDALA, Benjamin Junior. Literatura, história e política. São Paulo: Ateliê Editorial, 2007.

BARBOSA, João Alexandre. Entre livros. São Paulo: Ateliê Editorial, 2009.

BARTHES, Roland. Crítica e verdade. São Paulo: Ed. Perspectiva, 2009.

BENJAMIN, Walter. Obras escolhidas, magia e técnica, arte e política. São Paulo: Ed. Brasiliense, 2010.

CANDIDO, Antonio. Formação da literatura brasileira (momentos decisivos). São Paulo/Rio de Janeiro: FAPESP Ouro sobre Azul, 2009.

CANDIDO, Antonio et al. A personagem de ficção. São Paulo: Ed. Perspectiva, 2009.

COELHO, Nelly Novaes. Literatura infantil, teoria, análise, didática. São Paulo: Ed. Moderna, 2009.

CUNHA, Maria Zilda da. Na tessitura dos signos contemporâneos: novos olhares para a Literatura Infantil e Juvenil. São Paulo: Ed. Paulinas, 2009.

DEHEINZELIN, Monique. Construtivismo: A poética das transformações. São Paulo: Ed. Ática, 1996.

ECO, Humberto. Obra aberta. São Paulo: Ed. Perspectiva, 1971.

MACHADO, Ana Maria. Balaio: livros e leituras. Rio de Janeiro: Ed. Nova Fronteira, 2007.

PALO, Maria José; OLIVEIRA, Maria Rosa D. Literatura infantil: voz de criança. São Paulo: Ed. Ática, 2006.

SAID, Edward W. Representações do intelectual: as conferências de Reith de 1993. São Paulo: Cia. Das Letras, 2005.

SANTAELLA, Lucia. Por que as comunicações e as artes estão convergindo? São Paulo: Ed. Paulus, 2008. 